\title{
酸素イオン導電性を利用した金属一 ジルコニア接合
}

\section{野城 清* $^{*} \cdot$ 武田裕之 ${ }^{* 2} \cdot$ 阪下元貴 ${ }^{* 3} \cdot$ 荻野和已 $*$}

\author{
An Application of Oxygen Ionic Conductivity of Zirconia \\ to Metal-Zirconia Joining
}

Kiyoshi NogI, Hiroyuki Takeda, Motoki SaKaShITA and Kazumi Ogino

\section{Synopsis :}

A new joining method has been developed which is applicable to metal-zirconia systems.

This method has the following advantages ;

1. Ability to make joining without load,

2. Ability to make joining in a short time,

3. Ability to make joining to any surface area,

4. No oxidation of the metal surface,

5. Ability to control the thickness of the reaction layer,

6. No special equipment is required,

7. Ability to be used even with complex shapes,

8. Ability to be used with zirconia sprayed materials.

In the present work, chiefly, an Fe-zirconia system was investigated and it was confirmed that this method was applicable to other metal-zirconia systems.

Key words : ceramics ; joining; $\mathrm{ZrO}_{2}$; sprayed materials ; metal- $\mathrm{ZrO}_{2}$ joining.

\section{1. 緒言}

近年，材料の使用環境がますます厳しくなるのに対応 し, 高温における安定性, 耐食性, 耐摩耗性などの性質 に優れた酸化アルミニウム, 酸化ジルコニウムなどのセ ラミックスが，急速に注目を集めてきている1). しかし ながら, セラミックスには, このような長所がある反面, 機械的·熱的衝撃に弱く，脆いという非常に大きな欠点 を有している．そこで，この欠点を補いセラミックスの 長所を生かすため, 他の材料との複合化の技術が発展し てきている2．金属は，高温における安定性や酎摩耗性 には欠けるものの, 七ラミックスの有していない高勒性 という大きな長所を有しているため, 両者を複合化させ れば，お互いの短所を補い長所を生かすことが可能とな る. 現在, セラミックスの用途としては, ガスタービン のブレードや自動車用エンジン部品, その他機械構造用 材料など, 数多くある ${ }^{1)}$. 以上の観点から, より接合強
度が高く,より簡単な金属とセラミックスとの接合方法 の開発が期待されている.

しかしながら，七ラミックスと金属とでは，結合状態 が異なるため，耐食性などの化学的性質に加え，熱钐張 率などの物理的性質も異なることが多く，その接合は容 易ではない3). したがつて，現在までに，各種の接合技 術が提案されてきてはいるものの，その多くは，工程が 複雑であり，またセラミックスの加工性がそしいなどの 理由から, 複雑な形状の接合材料には, 適用できないな どの問題が含まれている.

本研究で検討を行つたセラミック、スはジルコニアであ り，これは，熱伝導性が低く，熱遮蔽用材料として注目 されているが4), ジルコニアと金属を直接接合させるこ とは, 困難な場合が多い。しかしながら, 両者の間に適 当な中間層を挿入すれば，接合も可能になると考えられ る. また, ジルコニアは, 上記の特性に加え, 高温にな ると酸素イオン導電性となることが大きな特徴として挙

昭和 61 年 10 月本会講演大会にて一部発表 昭和 63 年 3 月 28 日受付 (Received Mar. 28, 1988)

* 大阪大学工学部 工博 (Faculty of Engineering, Osaka University, 2-1 Yamadaoka Suita 565)

*2 大阪大学大学院 (Graduate School, Osaka University)

*3 大阪大学工学部 (現 : 久保田鉄工(株)) (Faculty of Engineering, Osaka University, Now Kubota, Ltd.) 
げられる。

そこで, 本研究では,このジルコニアの酸素イオン導 電性の性質を利用して，ジルコニア-金属界面に中間層 を形成し，ジルコニアと鉄を中心とした各種金属との接 合を試み，EPMA による界面観察および強度試験を行 つて最適な接合条件を得ることを目的とした。

\section{2. 実験}

\section{$2 \cdot 1$ 原理および方法}

純粋なジルコニア $\left(\mathrm{ZrO}_{2}\right)$ に $\mathrm{Y}_{2} \mathrm{O}_{3}, \mathrm{MgO}, \mathrm{CaO}$ な どの酸化物を添加すると, 室温から $2273 \mathrm{~K}$ を超える温 度範囲において, 立方晶構造をとる安定な材料となる が4)，同時に酸素イオンの欠陥構造となり，高温におい て酸素イオン導電性となる5). そこで，Fig. 1 に示すよ うに金属ージルコニアの界面に, 外部より直流電位を与 える電気回路を組むと, 金属-ジルコニアの界面を陽極 にすれば，ジルコニア表面から界面へ，また逆に，陰極 とすれば，界面からジルコニア表面への酸素の移動を起 こすことが可能となる.この二つの操作を, 単独で, あ るいは，連結して起こすことにより，例えば，界面にお いて金属の酸化を起こすことができ, 金属とジルコニア の間に，ある中間層を形成することが可能となる.

一例として，金属が鉄であり，鉄-ジルコニアの界面 に酸素の供給のみを行う場合について考えてみると，上 記の原理から界面において鉄が酸化され低級酸化物のウ

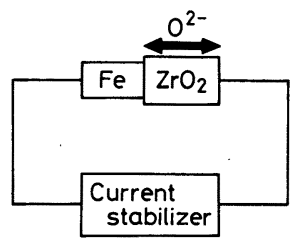

Fig. 1. Diagram for current circuit for joining experiment.

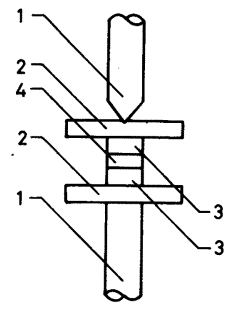

Type 1

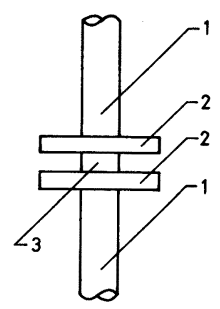

Type 2
1. Stainless rod 2. Fe disk 3. $\mathrm{ZrO}_{2}$ sample 4. Metal sample Fig. 2. Detail of setup for observation on metalzirconia interface after joining experiment.
スタイト $(\mathrm{FeO})$ が生成される. 一方, $\mathrm{FeO}-\mathrm{ZrO}_{2}$ 系 状態図 ${ }^{6)}$ にると，この系では， $1623 \mathrm{~K}$ 付近に共晶点 が存在しているため, $\mathrm{ZrO}_{2}, \mathrm{FeO}$ 両相が存在する界面 を,この共晶温度以上に加熱すれば，共晶組織の出現に より, 中間層が形成されることになり，鉄とジルコニア はこの $\mathrm{FeO}$ を介して化学的に接合することが可能にな ると考えられる.

実験は以下の手順で行つた．金属がニッケルの場合に は, Fig. 2 の Type 1 の方式で, 鉄の場合には, Type 2 の方式により，実験を行つた。ここでは，上下のステ ンレス棒が電極となつており，両極間に直流電位を与え ることにより，電流が流れることになる．各金属とジル コニア試料は，昇温開始前の振動等による界面の剝離を 避けるため, あらかじめ，有機接着剤にて接着した．以 上のように準備した試料を，雲井気による金属の酸化を 防ぐため, Ar 雲囲気中にて昇温し，実験温度に到達後， 所定の実験条件（電気量及び，通電電流）になるよう両 極間に直流電位を与えて通電を実施した。 その後，4～5 $\mathrm{K} / \mathrm{min}$ の速度で降温した。

このようにして得られた金属-ジルコニア接合対の試 料を界面に垂直に切断し，EPMAにより接合界面の様 相を観察した。

\section{$2 \cdot 2$ 試，料}

本研究で使用したジルコニア試料は， $15 \mathrm{~mol} \% \mathrm{MgO}$ を添加して安定化させたジルコニア（以下 ZR-15 M と 表す） [安定化度 95 (cubic\%)], $8 \mathrm{~mol} \% \mathrm{Y}_{2} \mathrm{O}_{3}$ を添加 して安定化させたジルコニア“同 ZR-8 Y) [同 100 (cubic\%)], および $9 \mathrm{~mol} \% \mathrm{MgO}$ を添加して安定化さ せたジルコニア（同 ZR-9 M）[同 30 (cubic\%)] の 3 種類である.

また，金属試料は， $\mathrm{Fe}, \mathrm{Ni}, \mathrm{Al}, \mathrm{Fe}-\mathrm{Ni}(33 \mathrm{wt} \%)$ 合 金を用いた. Fe，およびジルコニアと線膨張率が類似 している $\mathrm{Fe}-\mathrm{Ni}(33 \mathrm{wt} \%)$ 合金は，あらかじめ高周波 真空溶解炬中にて溶製したものである．また， Ni は市 販のニッケル棒材, $\mathrm{Al}$ は粉末状の試料を用いた。金属 およびジルコニアの両試料ともエメリー紙により鏡面研 磨を行い，アセトン中にて超音波洗浄を行つた後，実験 に供した。

\section{$2 \cdot 3$ 接合強度测定}

接合強度の評価は，4点曲げ試験により行つた。試験 を行うには，所定の長さの接合対が必要となるため， $\mathrm{Al}$ 以外の金属試料は直径約 $10 \mathrm{~mm}$, 厚さ $2 \sim 3 \mathrm{~mm}$ の円 盤状の試料, ジルコニア試料は, 長さ $24 \sim 25 \mathrm{~mm}$, 直 径約 $10 \mathrm{~mm}$ の円柱状試料を 2 個準備し, Fig. 3 に示す ようにセットした。この場合，電極となるのは金属試料 
に接続したリード線と, ステンレス棒であり, 両界面別々 に通電できるようになつている，Al は粉末のため, ジ ルコニア表面にアセトンを用いて塗布し，Fig. 4 に示 す方式により実験を行つた。この場合電極となるのは, 上下のステンレス棒である. 両者とも, 実験中に振動な どによる影響を除くため, 強度試験試料セット時は, 金 属ージルコニアの両界面を有機接着剂にてあらかじめ接 着させて书き，また，アルミナダイスを試料周辺に置い て保護した，界面観察の場合と同様，Ar 䨌囲気中にて 所定の温度，条件にて通電を実施した。 その後，4～5 $\mathrm{K} / \mathrm{min}$ の速度で降温を行い接合の得られた試料につい て強度測定を行つた. また強度測定後の試料についても, 随時 EPMA による界面観察を実施した。 なお，接合強 度 $\sigma_{b}$ は，次の式により算出した7).

$$
\sigma_{b}=8 F(l-2 c) d /\left(\pi d^{4}\right) \times 10^{-6}
$$

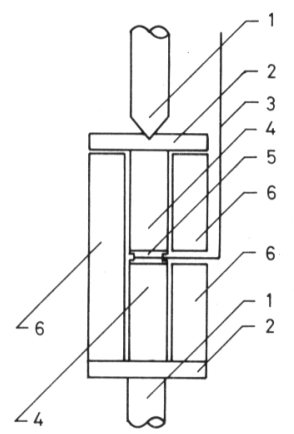

1. Stainless rod 2. Fe disk 3. Lead wire 4. $\mathrm{ZrO}_{2}$ sample 5. Metal sample $(\mathrm{Fe}, \mathrm{Ni}, \mathrm{Fe}-\mathrm{Ni})$ 6. Porous $\mathrm{Al}_{2} \mathrm{O}_{3}$ guide Fig. 3. Detail of setup for mesuring fracture strength of metal $(\mathrm{Fe}, \mathrm{Ni}, \mathrm{Fe}-\mathrm{Ni})$-zirconia joining sample.

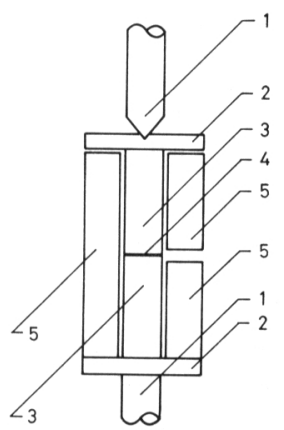

1. Stainless rod 2. Fe disk 3. $\mathrm{ZrO}_{2}$ sample

4. Metal sample ( $\mathrm{Al}$ powder) 5. Porous $\mathrm{Al}_{2} \mathrm{O}_{3}$ guide

Fig. 4. Detail of setup for mesuring fracture strength of metal (Al powder)-zirconia joining sample.

$$
=8 F(l-2 c) /\left(\pi d^{3}\right) \times 10^{-6}
$$

$\sigma_{b}:$ 接合強度 $(\mathrm{MPa})$

$l$ : 支持点間の距離 $(\mathrm{m})$

$c:$ 荷重点と接合点の間の距離 $(\mathrm{m})$

$d:$ 接合界面の直径 $(\mathrm{m})$

$F:$ 試料が破壊した時の荷重（N）

\section{3. 結果}

\section{$3 \cdot 1$ 鉄-ジルコニア接合対}

$3 \cdot 1 \cdot 1$ 界面観察

実験条件を Table 1 に示す。通電は一方向のみで実 施した。通電を実施した試料については, 陽極側の界面 ですべて反応した跡が見られ，一部接合したものも見ら

Table 1. Joining condition of $\mathrm{Metal} / \mathrm{ZrO}_{2}$ (15 mol\%MgO).

\begin{tabular}{rccccc}
\hline No. & Metal & $\begin{array}{c}\text { Temp. } \\
(\mathrm{K})\end{array}$ & $\begin{array}{c}\text { Voltage } \\
(\text { V })\end{array}$ & $\begin{array}{c}\text { Electric quantity } \\
(\mathrm{C})\end{array}$ & $\begin{array}{c}\text { Time } \\
(\mathbf{m i n})\end{array}$ \\
\hline 1 & $\mathrm{Fe}$ & 1623 & 2.0 & 2500 & 46.0 \\
2 & $\mathrm{Fe}$ & 1623 & 1.5 & 654 & 9.0 \\
3 & $\mathrm{Fe}$ & 1623 & 1.5 & 150 & 9.0 \\
4 & $\mathrm{Fe}$ & 1623 & 1.5 & 30 & 1.0 \\
5 & $\mathrm{Fe}$ & 1623 & 1.5 & 12 & 1.0 \\
6 & $\mathrm{Fe}$ & 1723 & 1.0 & 18 & 1.5 \\
\hline 7 & $\mathrm{Ni}$ & 1173 & 25.0 & 882 & 60.0 \\
8 & $\mathrm{Ni}$ & 1373 & 3.0 & 24 & 20.0 \\
9 & $\mathrm{Ni}$ & 1573 & 4.0 & 103 & 15.0 \\
10 & $\mathrm{Ni}$ & 1673 & 2.5 & 135 & 1.5 \\
\hline
\end{tabular}
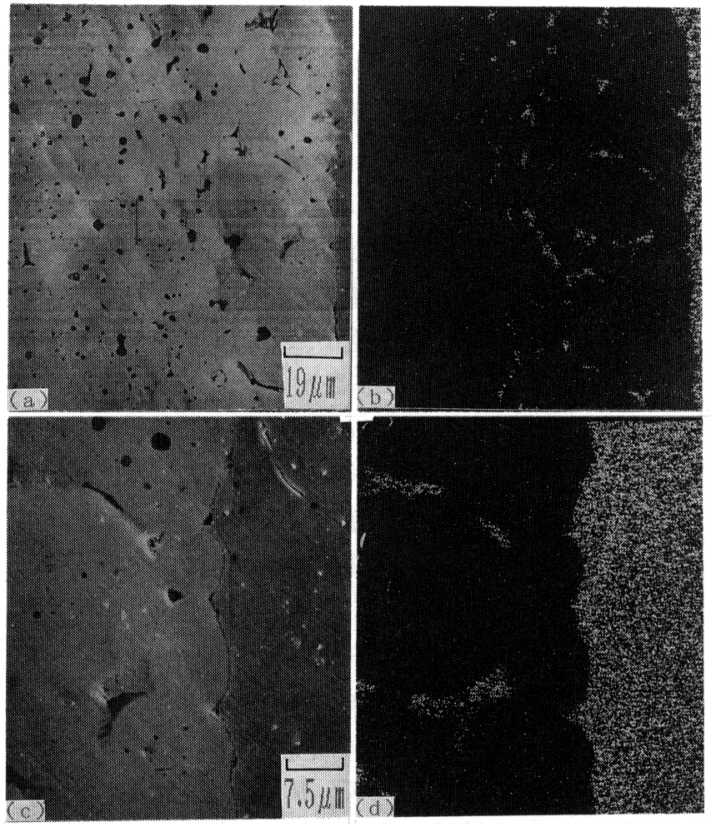

(a) S. E. M. image (b) Fe image (c) S. E. M. image (d) Fe image

Photo. 1. Reaction zone $\left(\mathrm{Fe}-\mathrm{ZrO}_{2}[15 \mathrm{M}]\right)$. 


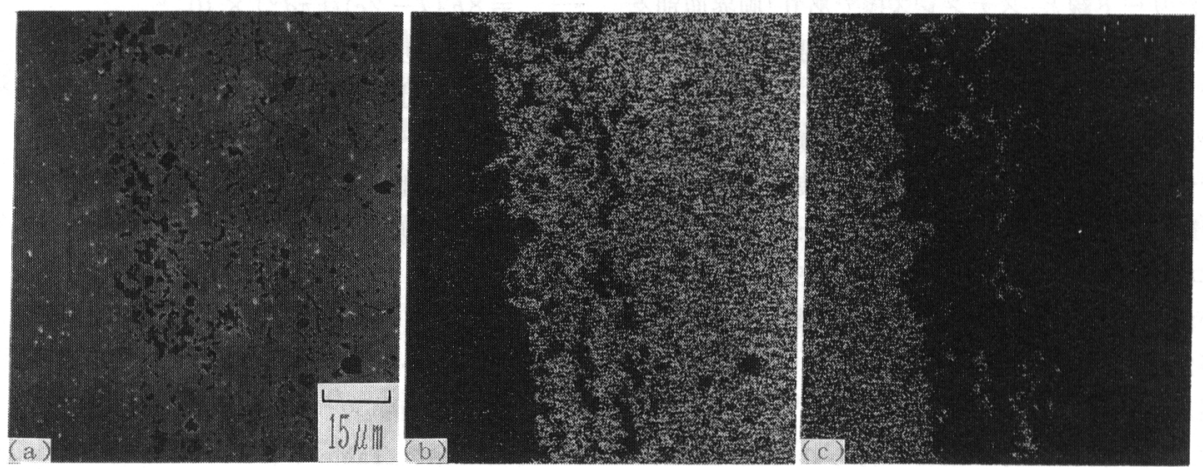

(a) S.E.M. image (b) $\mathrm{Zr}$ image $\quad$ (c) Fe image

Photo. 2. Reaction zone (Fe- $\left.\mathrm{ZrO}_{2}[15 \mathrm{M}]\right)$.

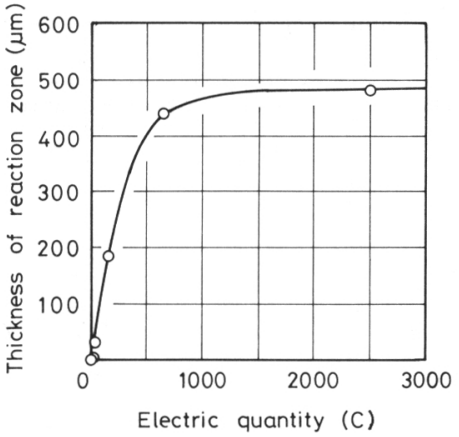

Fig. 5. Relation between electric quantity and thickness of reaction zone.

れたが，通電を行わず，同一温度にて保持した試料につ いては, 反応している様子は, 観察されなかつた。

鉄ージルコニア界面の反応層は, 黒色を呈していた. 泰松ら ${ }^{8)}$ は ZR-15 $\dot{\mathrm{M}}$ と鉄酸化物の反応層について, 鉄 酸化物が $\mathrm{FeO}$ の場合は黒色, $\mathrm{Fe}_{2} \mathrm{O}_{3}$ の場合には褐色に 着色すると報告しており，これより Table 1 のような 実験条件では, 界面にて $\mathrm{FeO}-\mathrm{ZrO}_{2}$ の反応が生じたも のと推察される.

$1723 \mathrm{~K}$ にて $18 \mathrm{C}$ の電気量（通電時間 $90 \mathrm{~s}$ ）を与え た場合の EPMAによる陽極側界面近傍の組織写真を Photo. 1 に示す. 鉄の分布四から, ジルコニアの粒界 に沿つて Fe が浸透している様子が観察されるが, Fe は，先に述べたことより $\mathrm{FeO}$ として浸透していると考 えられる.

Fig. 5 に $1623 \mathrm{~K}$ において，接合を行つた場合の界面 の反応層厚さと電気量 (電流入通電時間) との関係を示 す，四からあきらかなように，界面における反応層厚さ は電気量に大きく依存しており, 電気量が増加するとと
もに厚くなるが, ある程度以上になると電気量を増して も反応層厚さはあまり变化しなくなる.

一方, Photo. 2 に $1623 \mathrm{~K} に て, 30 \mathrm{C}$ の電気量（通 電時間 $60 \mathrm{~s}$ ）を与えた場合の組織写真を示すが,この 条件では反応層内にジルコニアバルク内に比べて, 非常 に多くのポアが見られることがわかる。また，1623 K では, かなり鉄の表面に凹凸が形成され，機械的にかみ 込んでいる様子が観察されるが, 一方, 温度が $1173 \mathrm{~K}$ の場合においては $882 \mathrm{C}$ (通電時間 $3.6 \mathrm{ks}$ ) という大き な電気量を与えて界面に酸素を供給した場合でも, 鉄表 面の凹凸は少なく機械的なかみ込みの効果は少なかつ た。

\section{$3 \cdot 1 \cdot 2$ 破壊強度測定}

実験条件および 4 点曲げ試験による接合強度結果を Table 2, 3 に示す. Table 2 中の I, II という表示は, 二つの界面を区別するために用いた。また Table 3 中 の“Joining ratio”とは, 界面の接着面積の割合を示す. 表中に示しているようにジルコニアとして ZR-15 M を 用いた場合が, ZR-8 Y, ZR-9 M と比較してかなり高 い接合強度を示した。 また, 接合試片がジルコニアバル ク内にて破断した場合の界面の接合強度は表に示した值 以上であると考えられる.

\section{$3 \cdot 2$ 他の金属-ジルコニア接合対}

$3 \cdot 2 \cdot 1$ 界面観察

実験条件を Table 1 に示す。金属が Ni の場合, 陽極 側界面では $1373 \mathrm{~K}$ までの温度が低い場合には, 界面の ジルコニアが黒く変色している程度であつたが, 1573 $\mathrm{K}$ 以上の場合には, ジルコニア表面が黒色を呈し, 緑 色の $\mathrm{NiO}$ が付着している様子が観察された. なお, ど ちらの場合も接合は得られなかつた。一方, 陰極側界面 では, 温度が高い場合ジルコニア側界面に灰色に変色し 
Table 2. Joining condition of Metal $/ \mathrm{ZrO}_{2}$.

\begin{tabular}{|c|c|c|c|c|c|c|c|}
\hline No. & Metal & $\mathrm{ZrO}_{2}$ & $\begin{array}{l}\text { Temp. } \\
\text { (K) }\end{array}$ & Interface & $\begin{array}{l}\text { Quantity } \\
\text { (C) }\end{array}$ & $\underset{(\mathrm{s})}{\operatorname{Time}}$ & Reference ${ }^{*)}$ \\
\hline 11 & $\mathrm{Fe}$ & $15 \mathrm{M}$ & 1723 & II & $\begin{array}{l}630 \\
600\end{array}$ & $\begin{array}{l}360 \\
360\end{array}$ & $\begin{array}{l}\mathrm{O} \\
\mathrm{O}\end{array}$ \\
\hline 12 & $\mathrm{Fe}$ & $15 \mathrm{M}$ & 1723 & I & $\begin{array}{l}18 \\
18 \\
\end{array}$ & $\begin{array}{l}90 \\
90 \\
\end{array}$ & $\begin{array}{l}0 \\
0 \\
\end{array}$ \\
\hline 13 & $\mathrm{Fe}$ & $8 \mathrm{Y}$ & 1723 & II & $\begin{array}{l}100 \\
100\end{array}$ & $\begin{array}{l}500 \\
500\end{array}$ & $\begin{array}{l}\mathrm{O} \\
\mathrm{O}\end{array}$ \\
\hline 14 & $\mathrm{Fe}$ & $8 \mathrm{Y}$ & 1723 & II & $\begin{array}{l}50 \\
50\end{array}$ & $\begin{array}{l}250 \\
250\end{array}$ & $\begin{array}{l}0 \\
0\end{array}$ \\
\hline 15 & $\mathrm{Fe}$ & $9 \mathrm{M}$ & 1723 & I & $\begin{array}{l}6 \\
6 \\
\end{array}$ & $\begin{array}{l}60 \\
60 \\
\end{array}$ & $\begin{array}{l}0 \\
0\end{array}$ \\
\hline 16 & $\mathrm{Fe}-\mathrm{Ni}$ & $15 \mathrm{M}$ & 1673 & II & $\begin{array}{l}18 \\
18\end{array}$ & $\begin{array}{r}90 \\
180 \\
\end{array}$ & $\begin{array}{l}\mathrm{O} \\
\mathrm{O} \\
\end{array}$ \\
\hline 17 & $\mathrm{Fe}-\mathrm{Ni}$ & $15 \mathrm{M}$ & 1673 & $\begin{array}{l}\text { I } \\
\text { II }\end{array}$ & $\begin{array}{l}18 \\
18 \\
18 \\
18 \\
\end{array}$ & $\begin{array}{r}90 \\
180 \\
90 \\
180 \\
\end{array}$ & $\begin{array}{l}O \\
\mathrm{R} \\
O \\
\mathrm{R} \\
\end{array}$ \\
\hline 18 & $\mathrm{Fe}-\mathrm{Ni}$ & $15 \mathrm{M}$ & 1673 & II & $\begin{array}{l}105 \\
105 \\
\end{array}$ & $\begin{array}{l}2100 \\
2100 \\
\end{array}$ & $\begin{array}{l}\mathrm{R} \\
\mathrm{R}\end{array}$ \\
\hline 19 & $\mathrm{Ni}$ & $15 \mathrm{M}$ & 1673 & II & $\begin{array}{l}1000 \\
1000 \\
\end{array}$ & $\begin{array}{l}2010 \\
2010 \\
\end{array}$ & $\begin{array}{l}0 \\
0 \\
\end{array}$ \\
\hline 20 & $\mathrm{Ni}$ & $15 \mathrm{M}$ & 1673 & II & $\begin{array}{l}90 \\
90\end{array}$ & $\begin{array}{l}180 \\
180 \\
\end{array}$ & $\begin{array}{l}\mathrm{R} \\
\mathrm{R}\end{array}$ \\
\hline 21 & $\mathrm{Al}$ & $15 \mathrm{M}$ & 1173 & - & 18 & 1800 & 0 \\
\hline 22 & $\mathrm{Al}$ & $15 \mathrm{M}$ & 1173 & - & - & 1800 & - \\
\hline
\end{tabular}

Table 3. Fracture strength of Meta $/ \mathrm{ZrO}_{2}$.

\begin{tabular}{|c|c|c|c|}
\hline No. & $\underset{(\%)}{\text { Joining ratio }}$ & $\begin{array}{l}\text { Fracture strength } \\
\quad(\mathrm{MPa})\end{array}$ & Fracture place \\
\hline & 83.8 & 30 & $\mathrm{ZrO}_{2}$ bulk \\
\hline 12 & 65.6 & 94 & $\mathrm{ZrO}_{2}$ bulk \\
\hline 13 & 81.2 & 16 & $\mathrm{ZrO}_{2}$ bulk \\
\hline 14 & 33.3 & 15 & $\mathrm{ZrO}_{2}$ bulk \\
\hline 15 & 86.0 & 9 & Interface \\
\hline 16 & 38.8 & 53 & Interface \\
\hline 17 & 23.9 & 160 & Interface \\
\hline 18 & 37.2 & 4 & Interface \\
\hline 19 & Not joining & & \\
\hline $\begin{array}{l}20 \\
21\end{array}$ & $\begin{array}{r}8.9 \\
83.7\end{array}$ & $\begin{array}{r}327 \\
73\end{array}$ & $\begin{array}{l}\text { Interface } \\
\text { Interface }\end{array}$ \\
\hline 22 & $\begin{array}{l}61.9 \\
61.9\end{array}$ & 37 & Interface \\
\hline
\end{tabular}

Fracture strength of $\mathrm{ZrO}_{2}\left(8 \mathrm{~mol} \% \mathrm{Y}_{2} \mathrm{O}_{3}\right)=134(\mathrm{MPa})$

た厚い反応層が観察され，特に $1673 \mathrm{~K}$ においては,こ の界面でかなり強く接合していた. Photo. 3 は,この 時の $\mathrm{Ni}$ と $\mathrm{Zr}$ の EPMA による界面近傍の線分析を示 しているが,これにより, 界面にて拡散層が存在してい ることがわかる.

\section{$3 \cdot 2 \cdot 2$ 破壊強度測定}

実験条件および接合強度結果を Table 2，3 に示す. ここで, Table 2 において Oxidation, Reduction とある のは，まず金属-ジルコニア界面に酸素を移動させた後， 界面からジルコニア表面に酸素を移動させたことを示し ている．金属が $\mathrm{Fe}^{-\mathrm{Ni}}$ 抢よび $\mathrm{Ni}$ の場合には, かなり 高い強度を示している場合も見られるが, $\mathrm{Ni}$ の場合, 接合界面積が非常に小さいため, 接合界面における摩擦

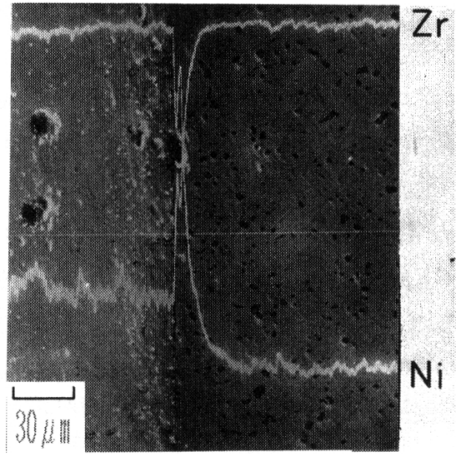

Photo. 3. Diffusion zone $\left(\mathrm{Ni}-\mathrm{ZrO}_{2}[15 \mathrm{M}]\right)$.

抵抗等の影響が考えられ, 信頼できる数值とはいえない. また，金属が $\mathrm{Al}$ の場合には，通電した場合と通電しな かつた場合とで強度にかなりの差が認められ, 電流を流 したことによる効果は, 強度的にほぼ 2 倍になることが わかる. 同時に 4 点曲げ試験時の破壊後の荷重隇少の様 子も他の金属との接合対と比較して大きな違いが見ら れ, 破壊が瞬時に起こらず徐々に起こり靶性のある様子 を示した。

\section{4. 考察}

\section{$4 \cdot 1$ 鉄-ジルコニア接合対の反応層厚さと電気量との 関係}

Fig. 5 に示すように陽極側界面に接合時に生成され る反応層は, 電気量がある程度以上大きくなると厚さが 増加しなくなる傾向が認められた．実験温度は $1623 \mathrm{~K}$ で,これは， $\mathrm{FeO}-\mathrm{ZrO}_{2}$ 系のほほ共晶温度であり，ま た界面に酸素を供給することにより生成される $\mathrm{FeO} の$ 融点, $1650 \mathrm{~K}$, より低い. したがつて, この温度では, 界面において $\mathrm{FeO}$ が生成された後 $\mathrm{FeO}$ とジルコニア の共晶反応により液相が生成され，これがジルコニアの 粒界に浸透することにより，接合が行われているものと 考えられる. 一方, 接合試片の実験終了後および強度試 験後の界面の破断の状況を観察してみると, 一般に, 電 気量を大きくした場合には, 界面で剥離する傾向が認め

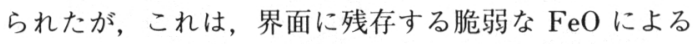
ものと考えられる. 以上のことから Fig. 5 の傾向は明 確ではないが, ジルコニアの粒界への液相の浸透速度が $\mathrm{FeO}$ の生成速度よりも遅かつたことによると考えられ る.

また,この結果から, 電気量を制御することにより, 界面の反応層の厚さを調節できることがあきらかとなつ た。 


\section{$4 \cdot 2$ 鉄-ジルコニア接合に及ぼす諸因子の影響} $4 \cdot 2 \cdot 1$ 温度

鉄-ジルコニア界面に酸素を移動させて, $\mathrm{FeO}$ を生成 させる場合, 温度が $\mathrm{FeO}$ の融点である $1650 \mathrm{~K}$ よりも 高いか低いかにより, 界面の様相が大きく異なる.

Photo. 2 と 1 に示した温度が $1623 \mathrm{~K}, 1723 \mathrm{~K}$ の場合 の界面の SEM 像からもわかるように，前者では界面に 凹凸によるポアの存在が認められるが, 後者の場合, ほ ぼ全面にわたりポアが存在せず，鉄とジルコニアが，良 好に接触している様子が認められる.

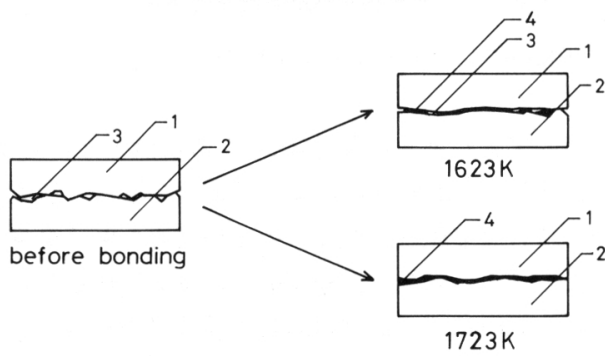

after bonding

1. $\mathrm{ZrO}_{2}$ sample 2. $\mathrm{Fe}$ sample 3. Pore 4. Interfacial layer Fig. 6. Schematic diagram of interface between $\mathrm{ZrO}_{2}$ and $\mathrm{Fe}$ at $1623 \mathrm{~K}$ and $1723 \mathrm{~K}$.
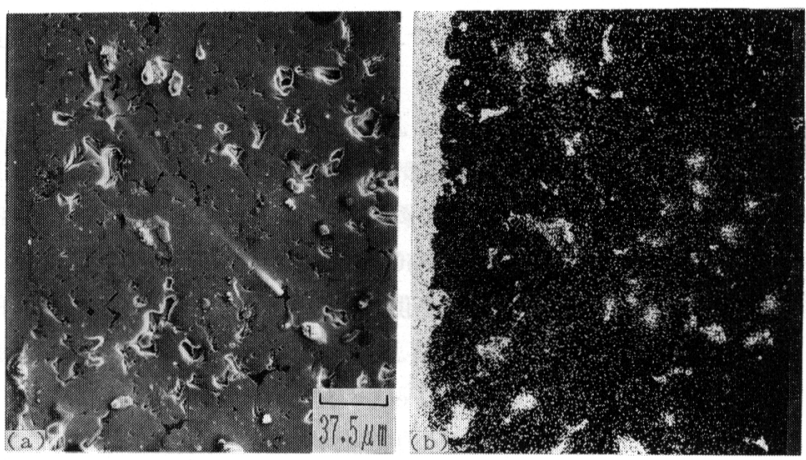

(a) S. E. M. image (b) Fe image

Photo. 4. Reaction zone $\left(\mathrm{Fe}-\mathrm{ZrO}_{2}\right.$ $[8 \mathrm{Y}])$
この場合の接合過程を考えてみる，通電前には，鉄と ジルコニアは，界面において Fig. 6 に示すような状態 で接触しており，全面完全に接触していない。したがつ て, 通電時 $\mathrm{FeO}$ が生成される領域は，この接触部分の みであり, $\mathrm{FeO}$ が固相の場合, 液相の出現には, $\mathrm{FeO}-\mathrm{ZrO}_{2}$ の共晶反応 (共晶温度, $1623 \mathrm{~K}$ 付近) を待 たねばならず，また，連続的に界面に酸素イオンが供給 され $\mathrm{FeO}$ が生成されるために，界面においては $\mathrm{FeO}$ と $\mathrm{ZrO}_{2}$ とでは, 量的に $\mathrm{FeO}$ の方が多く存在し, 界面 での液相量は，接触間のすき間をうめるには十分ではな い。それに対し, $\mathrm{FeO}$ が液相の場合には, $\mathrm{FeO}$ は生成 後, $\mathrm{ZrO}_{2}$ との接触部分において共晶反応を起こすだけ でなく，接触面全体に広がり，Photo. 1 に示すように 界面のすき間をうめることができるため, ポアは存在し なくなる.

$\mathrm{FeO}$ のジルコニアの粒界への浸透および界面でのポ アの存在と接合強度との関係について考えてみると, 界 面でポアが存在すると強度低下につながり，逆にポアを なくすために鉄-ジルコニア界面への酸素の移動量を多 くすると, $\mathrm{FeO}$ 生成量の増大とともに $\mathrm{FeO}$ はジルコニ アの粒界に深く浸透し, 冷却時に $\mathrm{FeO}$ の浸透層とジル コニアバルクとの膨張係数の相違による内部応力の増大
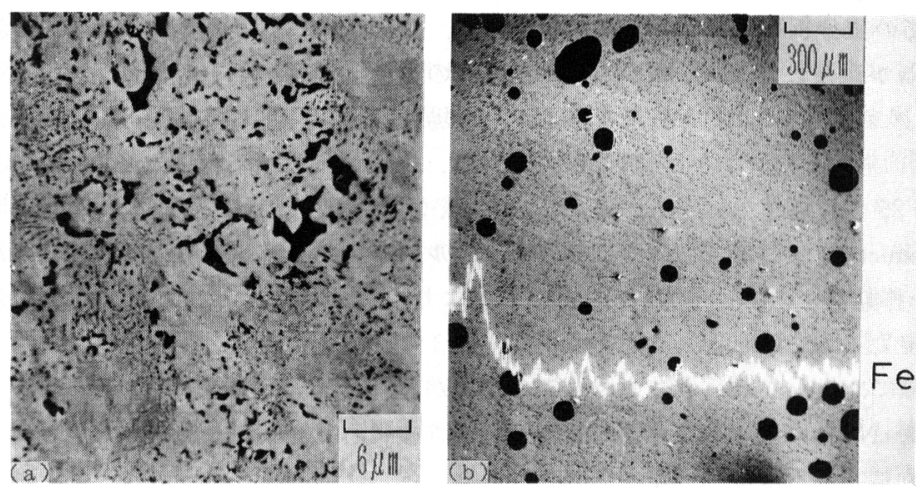
を伴うため，やはり強度低下を招くことになる．したが つて, $\mathrm{FeO}$ の融点以下では, 良好な界面は得られず, 高い接合強度を望むことはできない.

以上より，この場合ポアが発生しにくく，なおかつ $\mathrm{FeO}$ が界面で広がりジルコニアの粒界に浸透しやすい 状態となる $\mathrm{FeO}$ の融点以上で接合を行う方が, 高い接 合強度を望むことができると考えられる。

\section{$4 \cdot 2 \cdot 2$ ジルコニアバルクの粒径}

Table 2, 3 に示すように, 同一温度にて接合を行つ た場合でも, ジルコニアの種類により強度に著しい差異 が認められた。この影響として，ジルコニアバルクの粒 子径が異なつていることが考えられる. Photo. 1, 4, 5 に，それぞれのジルコニアの場合の界面近傍の SEM 像 を示す。このように最も高い強度が得られた ZR-15 M の場合には，他のジルコニアと比較して，粒が大きくは つきりしている様子が観察される.

上記三つの場合は, すべて $\mathrm{FeO}$ が液相として存在す る温度で接合を行つている. 粒径の大きい場合は, バル ク内のポアが大きく連続的となるため液相である $\mathrm{FeO}$ は，ジルコニアの粒界への浸透が容易となる．鉄とジル コニアを接合させるためには, $\mathrm{FeO}$ がある程度ジルコ ニアの粒界に浸透し，なおかつ界面で脆弱な $\mathrm{FeO}$ が多 量に存在しないことが必要となる。粒径が小さい場合, 液相が浸透しにくいため，このような状況を作ることが 難しい.

以上よりこのような機構により鉄とジルコニアを接 合させる場合, 粒径が大きい方が高い強度を望めるもの と考えられる.

\section{$4 \cdot 3$ 鉄-ジルコニア接合における最適条件について}

両者の密着性を向上させるためには, 界面でのポアは, できる限り少ないことが望まれ，そのため温度は，界面 に酸素を移動させた時に生成される $\mathrm{FeO}$ の融点 1650 $\mathrm{K}$ よりも高い方がよい. 鉄とジルコニアは, この $\mathrm{FeO}$ がジルコニアの粒界に浸透することにより接合している が, 浸透距離が大きくなると, 内部応力の増大を招き強 度低下につながるため, これはジルコニア 1 粒子層程度 とするのがよく, また, 界面にて脆弱な $\mathrm{FeO}$ が多量に 残存すると, 強度は低下するため, 界面に $\mathrm{FeO}$ 層がで きないようにする方がよい。したがつて，このような条 件となるように通電条件およびジルコニア粒径等を制御 する必要がある．例えば $\mathrm{FeO}$ の浸透速度より $\mathrm{FeO}$ の 生成速度を小さくするために, 低電流で長時間通電する か, あるいは外部より界面に圧力を加えて, 浸透を早め れば効果がでるものと思われる.

先に述べたようにジルコニアの種類により粒径が大き

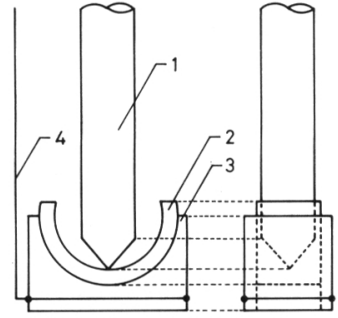

1. Nickel rod 2. $\mathrm{ZrO}_{2}$ sample 3. Fe sample 4. Lead wire Fig. 7. Detail of joining experiment for $\mathrm{Fe}$ zirconia which has a curved interface.

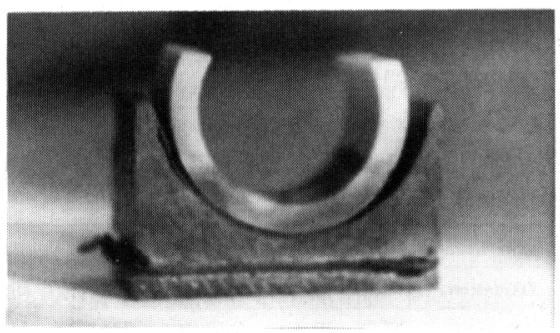

Photo. 6. Result of joining experiment.

く異なるため, 電気量, 界面への圧力, 通電時間等を調 整し界面において上記のような条件が満足されれば，強 度は増大するものと思われる。

\section{$4 \cdot 4$ 本研究における鉄-ジルコニア接合の応用例}

$4 \cdot 4 \cdot 1$ 曲面への応用

Fig. 7 に示す形式により界面が曲面である場合につ いて, アルゴン雰囲気下, 温度 $1673 \mathrm{~K}$ で $100 \mathrm{C}$ の電 気量にて界面に酸素を移動させて接合実験を行つた。実 験後の試料の様子を Photo. 6 に示す。このように曲面 試料の下端部にて接合していることが認められた。 それ 以外の場所では，すき間の生じている所があるが，使用 したジルコニア試料が焼結体のため完全な円形となつて おらず，実験前，鉄試料との接触が不完全であつたこと が，この大きな原因としてあげられる.しかしながら， 本研究は基本的に低荷重あるいは無荷重で行えるため, 界面の接触状態が良好となるような処理を施せば, 曲面 への接合に対しても有効な方法であると考えられる.

$4 \cdot 4 \cdot 2$ 溶射材料への応用

Fig. 8 に示す形式により鉄にあらかじめジルコニア のプラズマ溶射を施した試料について，接合実験を行つ た. 実験条件および結果の一部を Table 4 に示す. Table 4 中で Oxidation, Reduction とあるのは, 界面に まず酸素を移動させた後, 界面からジルコニア表面に, 


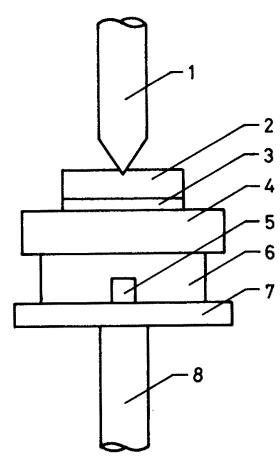

1. Nickel rod 2. Fe sample 3. Sprayed $\mathrm{ZrO}_{2}$ sample 4. $\mathrm{ZrO}_{2}$ disk 5. Hole 6. $\mathrm{ZrO}_{2}$ pipe 7. Fe disk 8. Stainless rod

Fig. 8. Detail of setup for Fe-sprayed zirconia joining experiment.

Table 4. Joining condition and joint strength of $\mathrm{Fe} /$ sprayed $\mathrm{ZrO}_{2}$.

\begin{tabular}{|c|c|c|c|c|c|c|}
\hline \multicolumn{3}{|c|}{ Experimental } & \multicolumn{3}{|c|}{ condition } & \multirow{3}{*}{$\begin{array}{c}\text { Joint } \\
\text { strength }\end{array}$} \\
\hline \multicolumn{3}{|c|}{ Oxidation } & \multicolumn{3}{|c|}{$\longrightarrow$ Reduction } & \\
\hline $\begin{array}{c}\text { Temp. } \\
\text { (K) }\end{array}$ & $\begin{array}{l}\text { Quantity } \\
\text { (C) }\end{array}$ & $\underset{(s)}{\text { Time }}$ & $\begin{array}{c}\text { Temp. } \\
\text { (K) }\end{array}$ & $\begin{array}{l}\text { Quantity } \\
\text { (C) }\end{array}$ & $\underset{(s)}{\text { Time }}$ & \\
\hline $\begin{array}{l}1673 \\
1673 \\
1673 \\
1673 \\
1673\end{array}$ & $\begin{array}{r}0 \\
100 \\
100 \\
100 \\
100\end{array}$ & $\begin{array}{r}0 \\
500 \\
500 \\
500 \\
500\end{array}$ & $\begin{array}{l}- \\
\overline{-} \\
1673 \\
1673 \\
1573\end{array}$ & $\begin{array}{l}\overline{-} \\
\overline{100} \\
500 \\
500\end{array}$ & $\begin{array}{c}\overline{-} \\
\overline{5} \\
2500 \\
2500\end{array}$ & $\begin{array}{l}\overline{-} \\
\text { Weak } \\
\text { Weak } \\
\text { Weak } \\
\text { Strong }\end{array}$ \\
\hline
\end{tabular}

逆に酸素を移動させたことを示す．なお，強度試験は， 絽返し衝撃密着性試験により行つた。この結果より, 本 方法がジルコニアの溶射材料へも適用でき，さらに界面 に酸素を移動させるだけでなく，その後，界面から酸素 を除くように電位をかけても接合に対し有効であること があきらかとなつた.

\section{$4 \cdot 5$ 本方法における鉄-ジルコニア接合の特幑}

以上の考察より, 下記のような特徴が挙げられる.

1 ) 無荷重あるいは低荷重にて行える.

2 ）寸法精度がよく，複雑な形状でも接合が可能であ る.

3 ) 微小な部分, あるいは広範井にわたる接合が可能 である。

4 ）界面部分の金属の酸化は雰囲気からのものではな く, ジルコニアを介して行うため, 金属母材は酸化され ない.

5 ）電気量を制御することにより, 外部から反応層厚
さを調節でき，接合のための最適条件を選択できる.

6 ）接合時間が短く，また通電電流および電圧も小さ く低エネルギーで行える.

7 ）ジルコニアを鉄に溶射した材料へも適用できる.

8 ) 特別な装置を必要としない.

\section{$4 \cdot 6$ 本研究における鉄以外の金属とジルコニアの接合 について}

$\mathrm{Fe}-\mathrm{Ni}$ 合金とジルコニアの接合では, 十分高い強度 を示している場合も見られるが, 界面における選択酸化 の問題等, まだ解決されていない問題が多くあり, 今後 の検討が必要である.

\section{5. 結言}

安定化ジルコニアが酸素イオン導電性の固体電解質で あることを利用して, 金属-ジルコニア接合試料に直流 電位を与え通電することにより，界面への酸素の供給あ るいは界面からの酸素の除去を行い, 両者の接合を試み た. EPMA および強度試験結果より得られた結果は, 以下のとおりである.

1 ）金属-ジルコニア試料に直流電位を与え, 界面に 酸素を供給すると,界面の金属を酸化することができる，

2 ) 鉄-ジルコニアの接合機構は, 酸化物 $(\mathrm{FeO})$ の ジルコニアの粒界への浸透である.

3 ) 酸化物のジルコニアの粒界への浸透距離は, 外部 より加える電気量の制御により調節することができる.

4 ) 本方法における鉄-ジルコニア接合の最適条件は, $\mathrm{FeO}$ がジルコニアの粒界に 1 粒子層程度浸透し, 界面 に酸化物が残存していないことである.

5 ) ジルコニアの粒子径が, 小さい場合には, 液相が ジルコニアの粒界に浸透しにくく接合させにくい.

6 ）本方法は, 鉄-ジルコニア界面が曲面の場合, お よびジルコニアが溶射材料でも適用できる.

\section{文献}

1 ) 例えば, 宇田川重和: 工業材料, 31 (1983)12, p. 2

2 ) 高塩治男: 工業材料, 30 (1982)8, p. 25

3 ) 石田洋一: 日本複合材料学会誌, 12 (1986) 3, p. 127

4 ) G. Johner and $K$. $K$. SchweItZer: Thin Solid Films, 119 (1984), p. 301

5 ）河波利夫，高木弘義: 工業材料, 30 (1982)8, p. 100

6 ) W. A. Fisher and A. HofFMAnN: Arch. Eisenhüttenwes., 28 (1957), p. 743

7 ) J. K. KLomP: Am. Ceram. Soc. Bull., 51 (1972), p. 683

8 ) 泰松 斉, 宮武克己, 金児紘征, 中谷文忠: 日本金属学会 誌, 46 (1982), p. 480 